\title{
Non-Administrative Models to Deteriorate Tax Evasion, a Socio-Cybernetic Application using NLP Archives for Taxpayer Euphoria Formation
}

\author{
Kanavas Vasilios ${ }^{1}$, Zisopoulos Athanasios $^{2, *} \&$ Razis Dimitrios ${ }^{2}$ \\ ${ }^{1}$ Law Faculty, Aristoteles University of Thessaloniki, Egnatia 156, Thessaloniki 546 21, \\ Thessaloniki, Ellas \\ ${ }^{2}$ Faculty of Mathematics and Informatics, University of Sofia Saint Kliment Ochridsky, Blvd \\ "James Bourchier" 5, 1164 g.k. Lozenets, Sofia, Bulgaria \\ *Correspondence: Faculty of Mathematics and Informatics, University of Sofia Saint Kliment \\ Ochridsky. E-mail: zisopoulos.athanasios.dim@gmail.com \\ Received: September 24, 2017 Accepted: October 15, 2017 Published: November 11, \\ 2017 \\ doi: 10.5296/rae.v9i3.11904ＵRL: https://doi.org/10.5296/rae.v9i3.11904
}

\begin{abstract}
With our Socio-Cybernetic Application we present a minimal approach to reduce tax evasion. Theoretically we use proven theories of Neuro Linguistic Processing, Christian Virtues influence, Cognitive Psychology guidelines, Tax collection and law enforcement principles. Our database are taxpayers, payments Beneficiary, Neuro Linguistic Programming reference points, Virtue points, etc. From the last two we create the Personal Human Space database with 1803 records. Then we analyze every person in the Taxpayers and money Receivers database and according to the theoretical guidance we formulate a specific limited human-space diagram for all 7 million persons and legal entities. As an example, we demonstrate the exact math and Matlab methodology to match a Taxpayer and money beneficiary with scoreboard 65 non-zero diagram points. The working system could be useful for Financial Intelligent Units, Economic Law enforcement agencies and Immigration Authorities.
\end{abstract}

Keywords: Tax Law, Tax Evasion, Tax Collection, Euphoria, Personal Data, Cognitive Psychology, Neuro-Linguistic-Programming, Mathematical Programming

\section{Journal of Economic Literature (JEL) Codes:}

K34, Tax Law, C63, Computational Techniques - Simulation Modeling C55, Large Data Sets: Modeling and Analysis, E71, Role and Effects of Psychological, Emotional, Social, and Cognitive Factors 


\section{Al Macrothink}

\section{Introduction}

Our research started after Greece realized the necessity to reduce tax evasion. In a previous work of us we introduced the concept for an intelligent settlement to collect state taxes as a semi-automatic procedure. Such a settlement is assembled primarily by state resources re-allocation like land allotment, service concession, patent use and others. (Kanavas 2017). Taxes collection remains always a severe state responsibility. In our research, we reverse the administrative approach and we introduce the self-contradictory term 'tax payment euphoria'.

The United States Declaration of Independence (Jefferson 1952) declares this euphoria the third basic right: "We hold these truths to be self-evident, that all men are created equal, that they are endowed by their Creator with certain unalienable Rights, that among these are Life, Liberty and the pursuit of Happiness." In Classical times the Athenians were proud about paying their own taxes and the city of Athens endorsed such a behavior. (Finley 1999, Thomsen 1964, Pavlitsas 2009)

Today there was a similar research (Stankevicius 2015) that proposes a new model by analyzing the Modern economic studies, the interaction between taxpayers, tax burden, social environment and country's economic development. They tailor, through behavior and social status analysis, an accurate psychological-social portrait of the tax evaders at the limits of the law.

Our methodology proposes a range of actions in the tax evasion avoidance field. From all these we only indicatively study a Neuro Linguistics Programming (NLP) (Grosu 2014, Stranovská 2013) knowledge base to satisfy taxpayer and payment beneficiary accordingly.

To introduce our methodology summary, we describe tables and databases used:

- $\quad$ taxpayers $=6194233$ (records), the Greek taxed for year 2016

- Beneficiary=566913(records), The Greek public servant as per today.

- NLP DB=1566(records), computer structure with basic NLP point

- Virtue $\mathrm{DB}=240$ (records), structure with Orthodox Virtues.

- Personal Human SPACE=1803(records) Our base reference structure.

- Taxpayer $\mathrm{ONE}=65$, The non zero diagram of the first taxpayer

- $\quad$ Taxpayer $\mathrm{TWO}=65$ (non zero element)

- Beneficiary=65(non zero element), The non zero NLP diagram points of the public funded beneficiary

- Taxpayer ONE=3058(scoreboard), Taxpayer $\quad$ TWO=2986(scoreboard), Beneficiary $=3042$ (scoreboard)

- final selection graph detail,

- Tax invoice after tax payment, Salary invoice, that the beneficiary paid from 
- Financial Intelligent Units

Through this research presentation we prefer the mathematical knowledge exemplification of matrix laboratory (Matlab) instead endless description.

Table 1. Methodology Pert Diagram

\begin{tabular}{|l|}
\hline G=digraph(vinit, vend, weights, vtxt); \\
\hline plot(G, 'Layout' , 'auto ', 'NodeColor', 'b'); \\
\hline
\end{tabular}

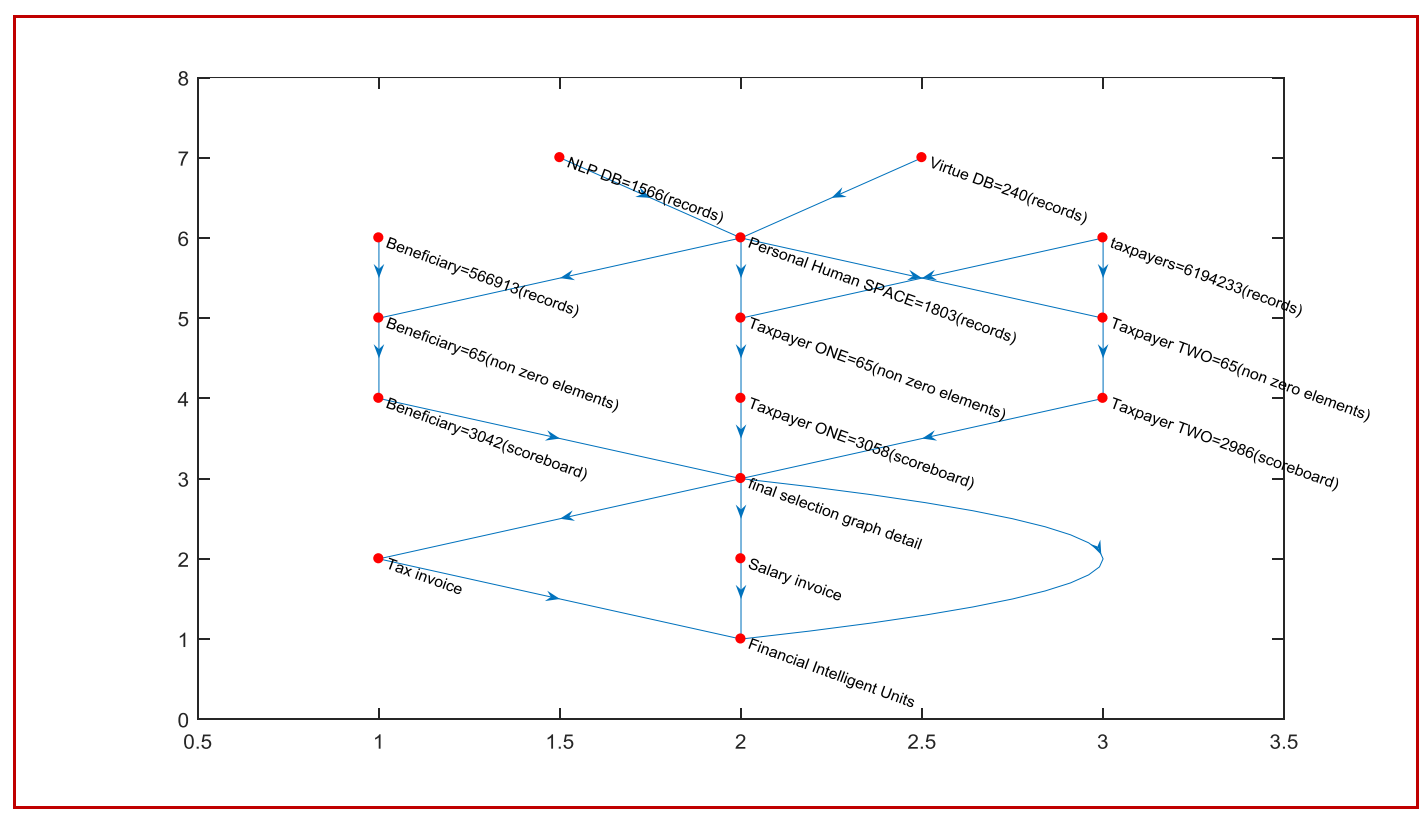

Figure 1. Methodology Summary (directed graph)

\section{Tax Collection}

The tax structure and taxpayer record layout is very sophisticated in our days. DeBats (2008) proved that United States shifted from a rural to an urban nation through taxation records holistic analysis of two divergent cities. Others they use tax data to fulfill its public facility apostleship. Savitri (2015) developed the concept of Tax socialization while Alm, (et al. 2010) propose new services and Kirchler, E., et al. (2006) use it for tax compliance. Tax evasion has been analyzed and brought us valuable development options. (Merks 2006, López2017, Carfora, et al. 2017).

Here we refer a number of non-administrative non-evasion options primarily by fulfilling the taxpayer inner space with alternative mind stipulating confusing functions.

- Tax payment dates different for every person, avoiding the media terrifying story telling.

- Tax dates after special dates like happy eastern lab eudemonia.

- Pico payments lower than 2 Euros per day or a few cents every hour 


\section{Macrothink}

The research of the above did not finished yet due severe complexity. We will present it at a later more mature stage.

\subsection{Tax Data Numbering and Sources}

Hellenic IRS data (AADE 2016) for tax payer data published the number of taxpayers in Greece are exactly 6,194,233 different persons and legal entities. This database has several hundreds of fields. The most important for our methodology is tax source field. It denotes the amount of money earned from various sources like salary, rent, stock, copyright payments. etc.

According to state authorities (Census 2016) The number of public servants in the Hellenic payroll state budget it is exactly 566913. Due to the huge nature of taxpayer database we have to use tall arrays in our Matlab implementation.

Table 2. Tall Disk Arrays Implementation for 6 Million Record 7 Fields Taxpayer Database

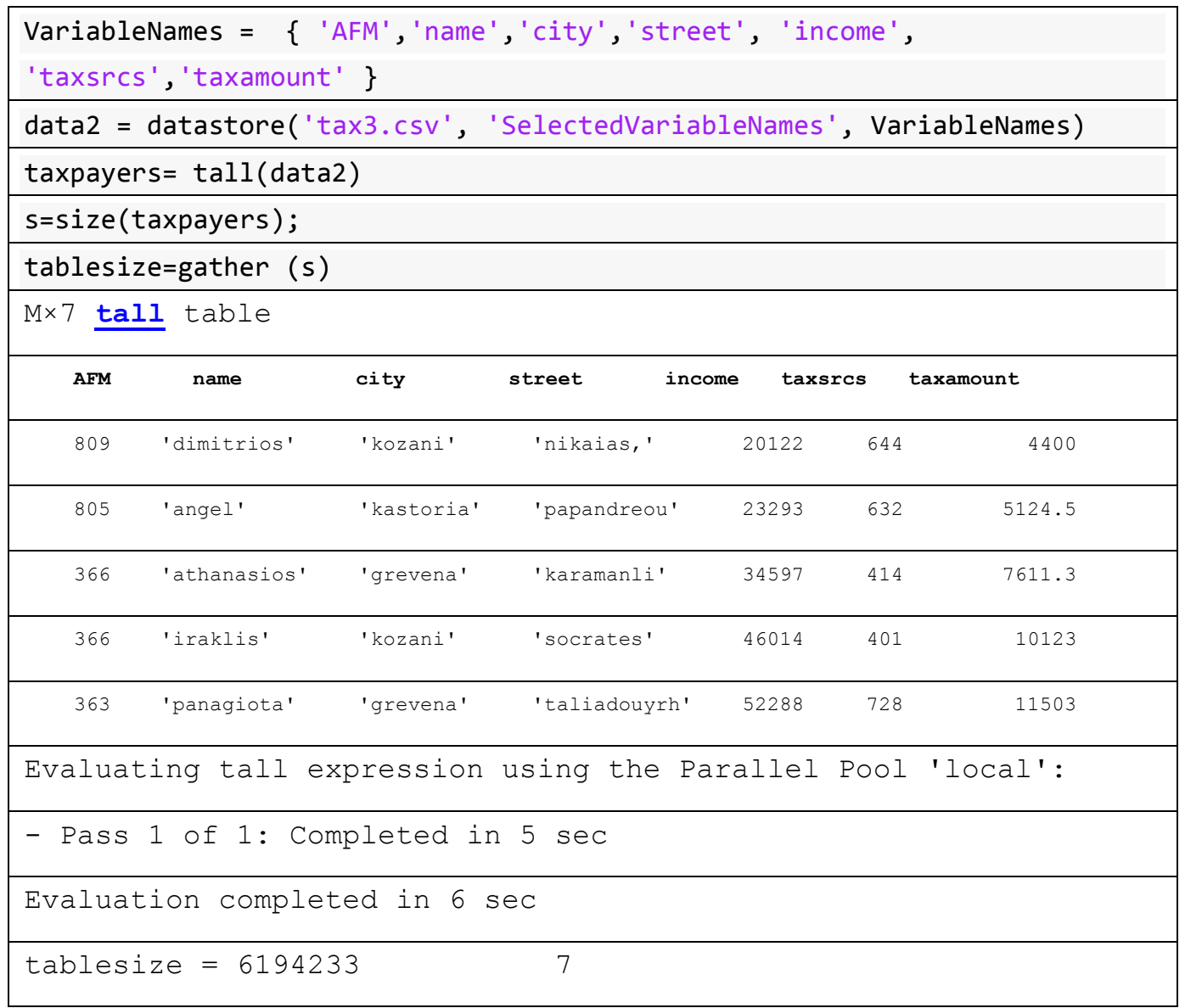

\subsection{Cognitive Psychology or Neuro Linguistic Programming?}

NLP _ Neuro Linguistic Programming, it is a mind language, pattern. There are patterns for all our activities. We learn, sleep, motivated, love, dine, exercise, keep a job, get frustrated, 


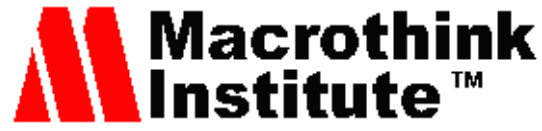

be happy, all. Cognitive psychology advices that possibly there is a chemical reaction for everything. Each such a well-defined pattern is pre-empted by a thought (conscious or unconscious) and chemicals. In our current research we examine the NLP modelling nature. There is a scientific group of NLP explorers modelled triggers questions like "what are they doing that is working so well?". (Nevis, 2014, Staemmler 2016, Young2017)

Apart from this initial curiosity they modelled their excellent strategies and created processes which could be applied in a variety of situations. NLP is a tool to understand how the language of our mind creates and runs the patterns we have in life. There are a variety of NLP techniques such as the Swish Pattern, Parts Integration, Neuro-Logical Levels Alignment, Reframing, Clearing Emotions, Imprinting, etc. For selected agencies, NLP is altogether a media tool, a negotiation tool. (Hassan 2014, Albalawi 2014, Sanusi 2014)

With all these in mind we preliminary assembled a NLP structure with 1566(records). This structure is rather complicated because it has to deal with multi-dimensional spaces, common Matlab tools and advanced future developments. In our today's presentation it could be as simple as a data dictionary.

\subsection{NLP Table Elements}

To interfere with NLP, we assembled all possible constituting element of personality and ego. (Yao 2017, Qiao, M., et al. 2017)

A graph with table format could be:

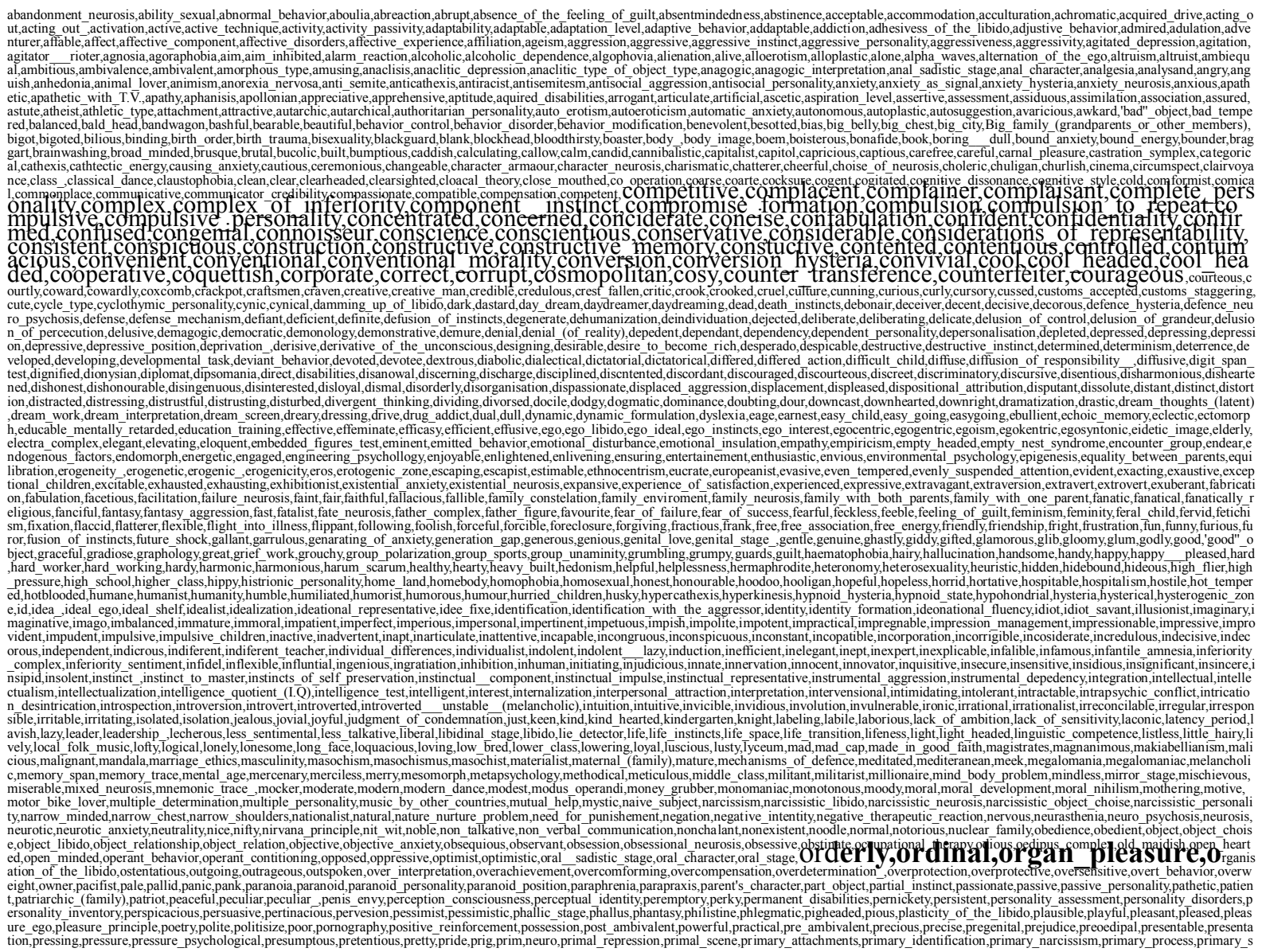




\section{Macrothink}

chool,principle of constancy,principle of neuronic inertia,principle_of reality,private,proconscious,prodigal,profiteer,progressive,projection, projective identification, prolific,prominent,promiscuous,prose,prosocial_behavio

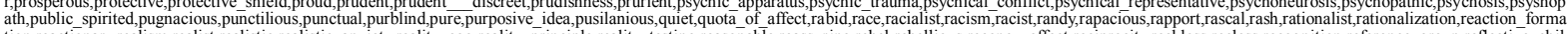

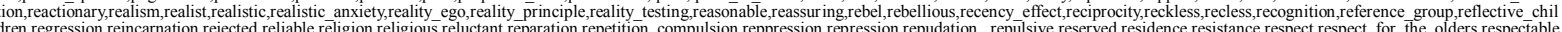

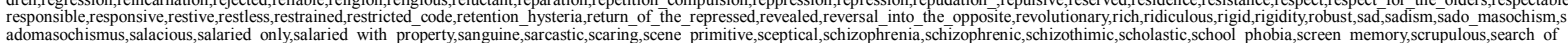

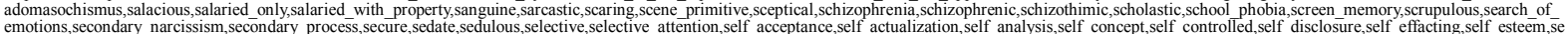

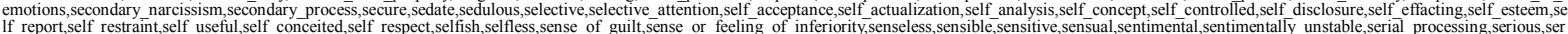
vile,severe _ strict,sex_role_behavior,sexual_aggressiveness,sexual_apostrophe,sexual instinct,sexual _timulation,sexuality,sexually_reserved,shabby,shady,sharing,shock_reaction,short hands _legs,shrewd,shy,signal of anxiety,simple_plain,sincere,single sports,sisters _ brothers,situational attribution,skilful,skinhead,slim,slothful,small,small_neck,smart,sneaky,snug,sober,sociable,social_cognition,social_exchange _theory,social_learning _ heory,social norms,social_rues.

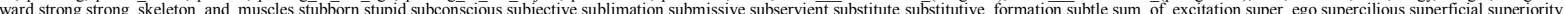

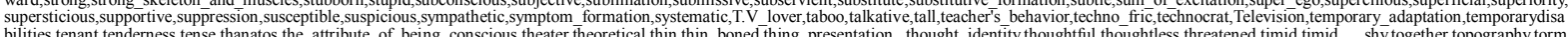
bilities, behavior pattern,typical, unattractive, uncertain, unchanged, unconcerned, unconscious, uncontrollable, underachievement, underdeveloped, understanding, undiciplined, undignified, undoing, undoing (what has been done), uneaš unfeeling,unfriendly,unhelpful, unimaginative,university,unjust,unkind, unloving, unppity,unreliable,unresonable, unsociable, unstable,unstable extroverted_(choleric), unsuccessful,untamable,unworthy,urethral_erotism, utilitar

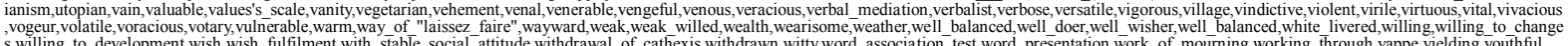

Figure 2. 1803 NLP reference Names at Minimal Resolution

\subsection{Osios Damascenus Virtues}

During Second World War Franciscan studies (Lenhart 1943) analyzed Saint John Damascenus work. The somatic virtues are formed by chastity, fasting, watches, sobriety, standing posture, genuflexions, use of one tunic, foregoing the luxury of bathing, use of only dried food, abstaining from wine, sleeping on the floor, poverty, solitude, silence and the like. Contrary to the virtues are two series of vices. The first series called also psychic is formed by distraction, sloth, ignorance (mother of irreligion, heresy and blasphemy), fury, anger, inhumanity, detraction, rash judgment, depression, fear, envy, conceit, lying, selfishness and avarice, root of all evils. The second series of somatic vices consists of gluttony ..., murder Finally, in his exposition of orthodox faith St. John Damascene gives another classification of vices according to psychological aspects. We do not want to interfere with evil, therefore from Saint Damascenus work we isolated the 240 Virtues. These has the form of a computer complex structure.

\subsection{Sample NLP-Virtue Table Psych Gram}

The NLP data structure and the Virtue data structure has been homogenized in a Personal Human Space with 1803 records. This is the main database for this presentation. For every person in the database we calculate his personal data and we prepare a NLP-Virtue Diagram in the form of a subset of Personal-Human-Space diagram. This is the most difficult part of the research and it will take years to acquire accepted accuracy. Problems are:

- Contradictory previous research from the international Science Community.

- Risky for every person and the society as whole.

- Analysis is difficult programming is very awkward. 


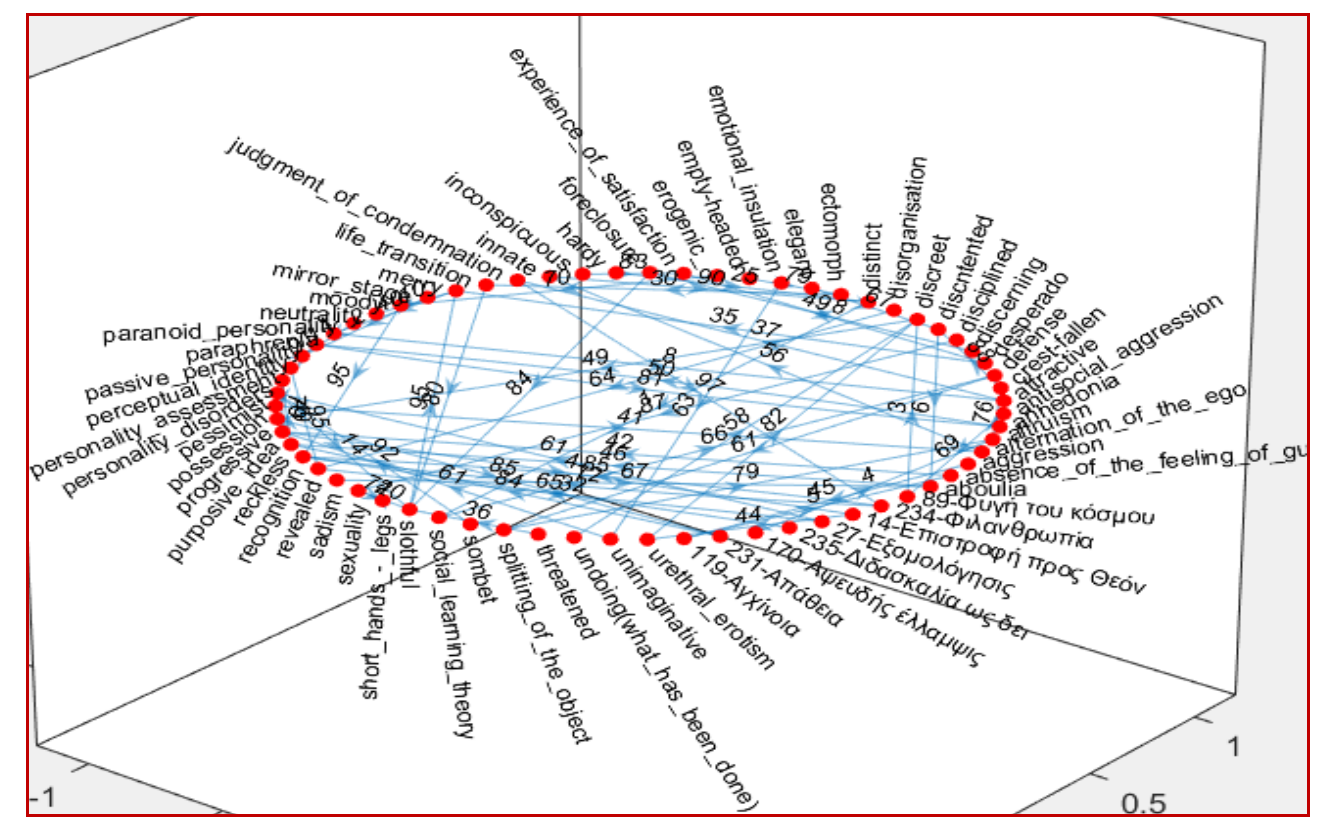

Figure 3. Taxpayer ONE $=65$ (interconnection for no zero elements)

\subsection{Euphoria Creation}

Apart of Classical Hellenic Philosophers, Israel Prophets and American Constitution in our times a handful researchers analyzed the concept of euphoria creation. Ali (2014) offered a unique perspective on innovation, he proved that innovation is independent of the social and political aspects of any society and he well defined interrelated issues innovation, optimism, and economic growth. A similar economic view expressed Arvin (et all 2014) by connecting the income with the life satisfaction.

Other researchers analyze various happiness aspects. Aydin (2012) argued that authentic happiness is possible with all elements of human nature. The paper offered a new comprehensive theory on human nature. More close to our technological approach reaches Hornung (2006) with his socio-cybernetic approach, combining systems concepts with orientation theory served as an integrative theoretical framework for so far separate theoretical approaches. Since happiness, workplace and education are close researchers examine this relation (Dean 2015, Pryce 2014, Robertson 1969).

Maslow in his famous work "hierarchy of needs" clearly elevated this euphoria as a high priority on human psychology. His original work is used today for similar purposes (Lester 1990), (Noltemeyer 2012, Williams 1989,Zavei 2012)

\subsection{Senses Irritation}

Euphoria empirically comes through the five basic senses fulfillment and twenty more (Howes 2015, Pilehvar2015). It is very easy to associate smell or food to a person but irritating a person for taxpaying reasons, it is beyond of our civilization. This propaganda approach it could be useful as a last step before a total war between rich and poor occurrence. 


\subsection{Everything or Nothing Sister Soul Finding}

Apostle Jacob in his Epistle writes: "For whoever keeps the whole law but fails in one point

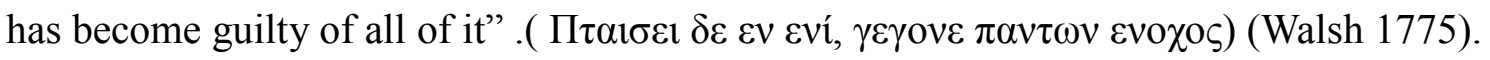

Our approach to find the "sister soul" to transfer our paid tax amount is strictly "Everything or nothing". Of course, there are other similar souls in this universe but only one matches all my exact believes and hopes. Therefore, our methodology is searching only exact matches, downgrading to partial matching if an "one to one" brotherhood is not found. This process is undefined and undocumented. Today we only use simplified subset for tax evasion purposes.

\section{Math Tax-Euphoria Matching}

\subsection{NLP-Virtue Array of Taxpayer and Beneficiary Creation Example}

One of the crucial problems is that we have to create an interrelation database of personal data. The law of European Union defines that, in order to proceed a taxpayer database manipulation, we need a written permission for an independent Authority. (Barnard 2017, Pavlitsas et all 2009). The scope of this paper far exceeds this data analysis.

\subsection{Conceptual Approach Tax Payer-Beneficiary Search and Associate}

Table 3. Matlab Code to Search and Match Two Database

\begin{tabular}{|l|}
\hline for $i=1: 6194233$ \\
\hline$\%$ for a single taxpayer a match is attempted \\
\hline \%through a whole search in the beneficiary array \\
\hline for $j=1: 566913$ \\
\hline match=tax_payer_beneficiary_match $(A, B)$ \\
\hline End \\
\hline
\end{tabular}

That huge endless loop it takes a lot of CPU and hard-disk time on modern Pcs. The actual timing is unknown with the use of tall array since they're using the (SSD or M.2) disk. We are afraid that things are tough for our i9 lab PC. For the inner match loop the program without runtime code it needs 70 seconds. That is two weeks (13.73909 days) for a complete batch.

Since these "match" function is not a simple function but in the future it will be more complicated and computer resources demanding we plan a number of computer programming old techniques. Like classifying taxpayer arrays according to the total NLP points each one has.

\subsection{Final Match, Where Two Taxpayers Match a Beneficiary}

For a given beneficiary we found two taxpayers with the exact NLP-virtues diagram array. 
Taxpayer ONE and TWO have identical NLP-diagram arrays. The program is:

Table 4. Matlab Code to Compare Three Arrays

\begin{tabular}{|l|}
\hline sum(taxpayer1Logical) \\
\hline size(taxpayer1) \\
\hline size (taxpayer2) \\
\hline test1 = eq(taxpayer1Logical, BenefLogical) \\
\hline test2 = eq(taxpayer2Logical, BenefLogical) \\
\hline sum(test1) \\
\hline sum(test2) \\
\hline a=sum(taxpayer1) \\
\hline b=sum(taxpayer2) \\
\hline c=sum(Beneficiary) \\
\hline abs(c-a) \\
\hline abs(c-b) \\
\hline
\end{tabular}

The calculation results are:

Table 5. Methodology Cornerstone to Find Sister Soul

\begin{tabular}{|c|c|c|c|}
\hline \multicolumn{3}{|c|}{ ans $=65$} & $\begin{array}{l}\text { The number of non zero elements on taxpayer ONE, } \\
\text { and TWO }\end{array}$ \\
\hline \multicolumn{2}{|l|}{ ans $=$} & 1803 & Total taxpayer ONE array size (mostly with zeroes) \\
\hline \multicolumn{2}{|l|}{ ans $=$} & 1803 & Total taxpayer TWO array size \\
\hline \multicolumn{3}{|c|}{ test $1=1 \times 1803$ logical array } & Comparison taxpayer ONE to Beneficiary \\
\hline \multicolumn{3}{|c|}{$\begin{array}{l}111111111111111111111111111111111111 \ldots \ldots \ldots .11 \\
111111111111111111111111111\end{array}$} & All LOGICAL 1 = TRUE \\
\hline \multicolumn{3}{|c|}{ test $2=1 \times 1803$ logical array } & Comparison taxpayer TWO to Beneficiary \\
\hline \multicolumn{3}{|c|}{$\begin{array}{l}111111111111111111111111111111111111 \ldots \ldots \ldots .11 \\
11111111111111111111111111\end{array}$} & All LOGICAL 1 = TRUE \\
\hline \multicolumn{4}{|c|}{ ans $=1803$} \\
\hline \multicolumn{4}{|c|}{ ans $=1803$} \\
\hline \multicolumn{3}{|c|}{$a=\quad 3058$} & Scoreboard of taxpayer ONE \\
\hline \multicolumn{3}{|c|}{$\mathrm{b}=\quad 2986$} & Scoreboard of taxpayer TWO \\
\hline \multicolumn{3}{|c|}{$\mathrm{c}=\quad 3042$} & Scoreboard of beneficiary \\
\hline \multicolumn{3}{|c|}{ ans $=\quad 16$} & Deviation between taxpayer ONE and beneficiary \\
\hline \multicolumn{3}{|l|}{ ans $=$} & Deviation between taxpayer TWO and beneficiary \\
\hline
\end{tabular}

During "test1" and "test2" we compare all 1803 elements of taxpayer ONE and the money beneficiary. We found that all three arrays are equal. This is the initial short eligibility list. Furthermore, we dive into the virtue calibration to find an exact match. The taxpayer ONE has deviation from beneficiary base reference psycho-gram 16 points, while the SECOND more than three times more. 


\section{I Macrothink}

\subsection{Differences Visualitation}

The general NLP-gram is visualized like this:

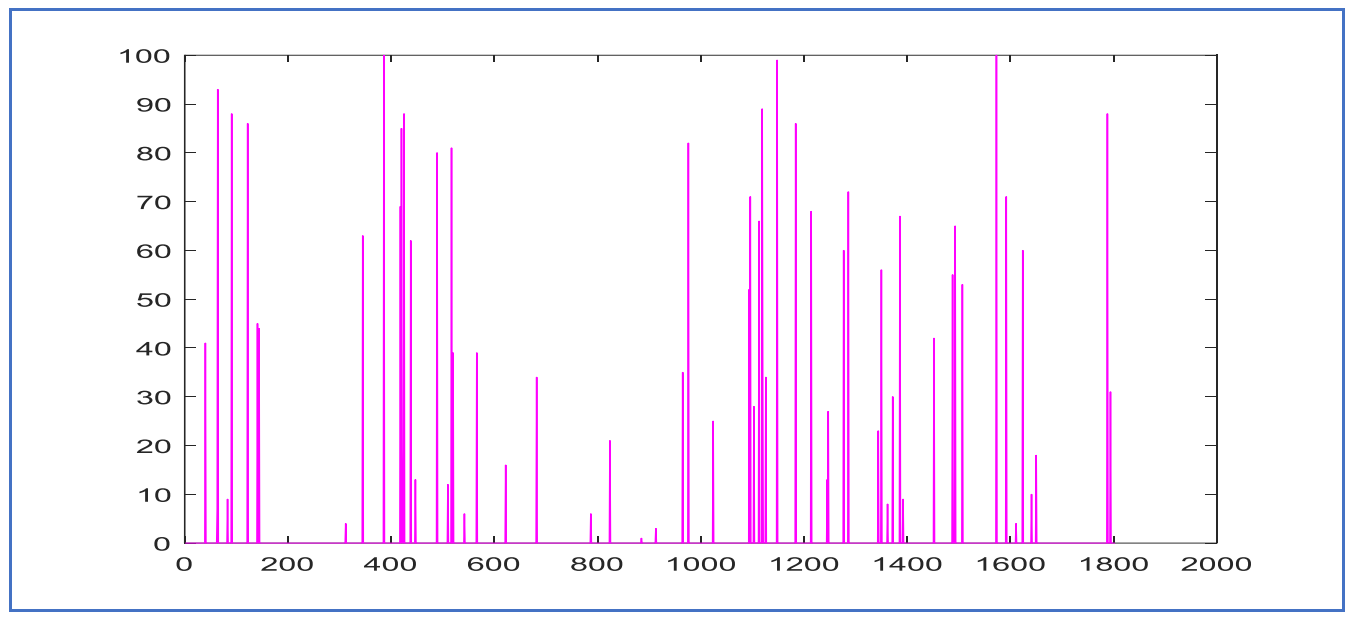

Figure 4. Personal Human SPACE=1803(records) for All Three Persons

The code plots the three NLP-grams.

Table 6. Focus into NLP pont 141 ("slow to anger") for All Three Persons

\begin{tabular}{|l|}
\hline hold on \\
\hline zoom on \\
\hline plot (taxpayer1, 'red') \\
\hline plot (taxpayer2, 'magenta') \\
\hline plot (Beneficiary, 'green', 'linestyle', '-.' ') \\
\hline$x \lim \left(\left[\begin{array}{ll}0 & 20\end{array}\right]\right)$ \\
\hline$y \lim \left(\left[\begin{array}{ll}0.09 .4\end{array}\right)\right.$ \\
\hline
\end{tabular}

To understand the differences, we focus into the point 143 of total 1803 human space graph of the three persons. This slight difference of our calculations is presented in the drawing below. 


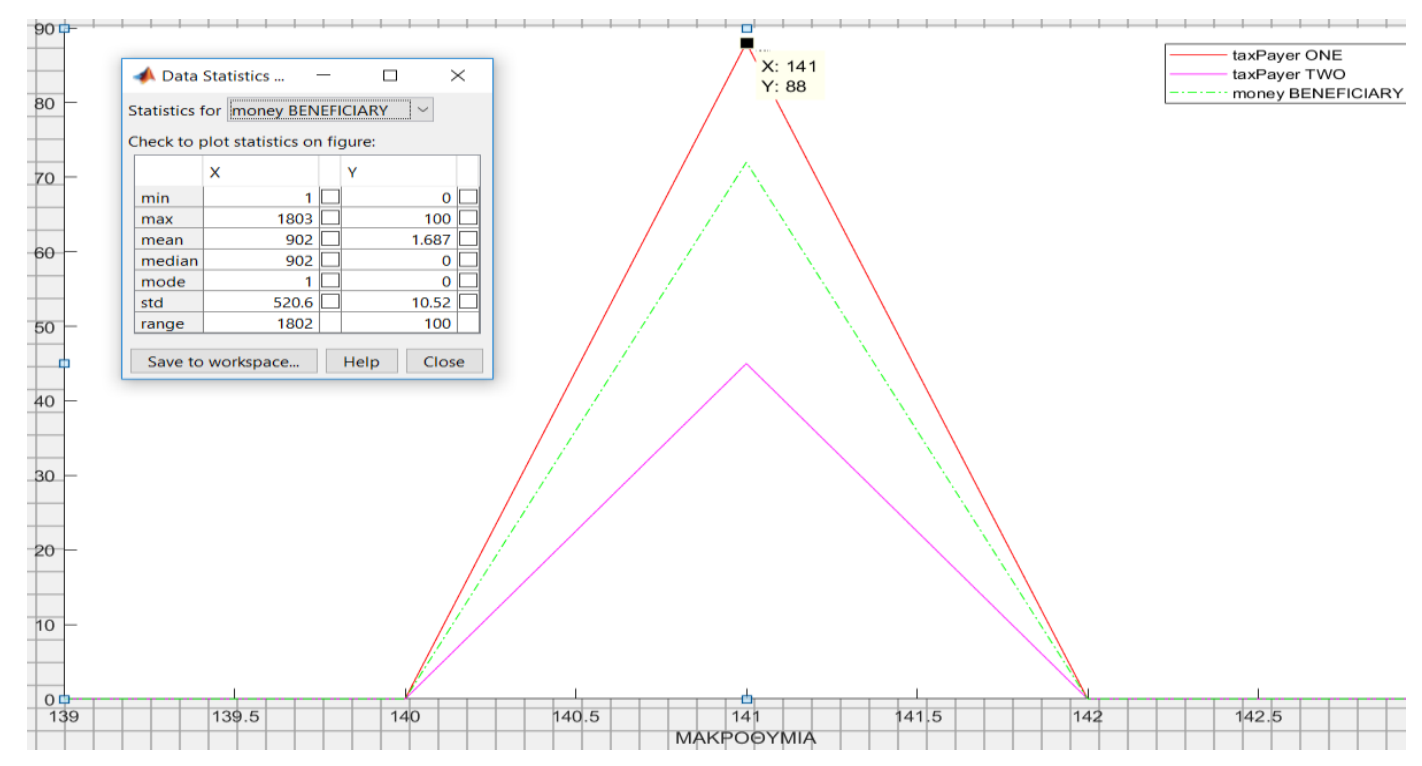

Figure 5. Final Selection Graph Detail

All differences are on NLP-point 141. According to our internal classification this is

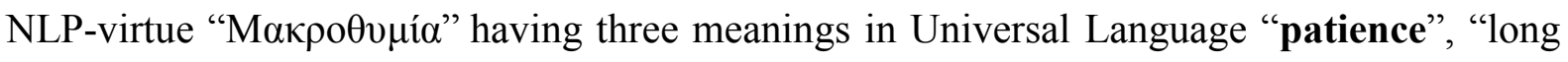
suffering" and "slow to anger", while none of the them is accurate.

The taxpayer "TWO" (magenta line) has this "slow anger" at 43 points, the money beneficiary (green line) has it higher at 73 points (being a better person) and the taxpayer "ONE" has it at 88 points. The taxpayers distance from beneficiary scoreboards the twin of payer-ONE and Beneficiary as the "sister souls".

\section{Results}

The pre alpha test of our methodology is accomplished successfully.

All the above steps are necessary to associate two persons. The tax agency locates the two "sister souls" with a variety of possible practical steps.

Further NLP analysis exceed the scope of this paper. We only give a low level example that brings satisfaction to the society.

Dimitrios is a University professor with significant work in defense systems. He receives a tax invoice that it indicates exactly:

"Zlonorable professor Dimitrios, your obligation to the Hellenic Republic for income tax is exactly 16232 Euros, payable in 3 equal installments. These money represent the annual salary of George Dapa* working for the Hellenic Vehicle Corporation, defense systems division...."

Figure 6. Tax Invoice

On the other end of the credit line George Papadopoulos in his monthly salary invoice he reads every month: 
"Xr. George Dapadopoulos your salary this month paid mainly from Prof Dimitrios Zisopoulos. Our country tax system thanks him for his contribution to your salary and the national defense effort of Greece..."

Figure 7. Salary Invoice

\section{Discussion}

There are severe problems to solve and additional systems to be prepared in order to present to the science and society a viable alternative to tax evasion. Problems are:

- Inaccurate NLP taxpayer-beneficiary profile formation.

- Limited computer capabilities.

- Cyber phobia for personal data use.

- Media and Facebook chat-talking.

We hope that in two years we could present a full featured working system.

Scientific community was not ready to discuss our humanitarian approach of poverty. Today things were changed, our ideas won a Noble prize. The winner of this year's Nobel prize in economics, is Richard Thaler of the University of Chicago. Thaler is known for his lifelong pursuit of behavioural economics (and its subfield, behavioural finance), which is the study of economics (and finance) from a psychological perspective. For some in the profession, the idea that psychological research should even be part of economics has generated hostility for years.

\section{Conclusion}

A last minute development is the modification of our computer systems. The above numbering is outdated. Our main computers today run at RAID various levels and achieved Crystal report $24 \mathrm{~Gb} / \mathrm{sec}$ so far, increasing constantly hopefully to 60 .

This methodology was not an academic exercise. The realization of the above leads in a true, legally approved, full feature system to facilitate a wide range of "deep state" functions. Existing and future parts of the methodology, after permission from Hellenic Data Protection Authority, are useful for methodology Services like European Financial Intelligent Units, National Economic Law enforcement agencies and of course the immigration problem.

\section{Acknowledgements}

We thank our professors from Sofia University

- Prof Alexander Dimov,

- Prof Leda Minkova

- Prof. Vladimir Dimitrov 
We also thank Prof Dr Dr Serdaris Panagiotis from West Mac University of Applied Sciences. By helping us on this research paper Prof Serdaris remembered his first PHD from Sofia university, Department of Social, Work and Educational Psychology.

Finally we thank Sir Iraklis Mavromatidis for his everlasting support of our preliminary research ideas and his effort to convert them into society progression.

\section{References}

AADE (Hellenic IRS)," tax table of year 2016", [WWW page]. Retrieved from http://www.aade.gr/sites/default/files/2017

Albalawi, Khawla Saad. (2014). Effectiveness Of Neuro-Linguistic Programming On Enhancing University Students'quality Of Life. International Journal of Arts \& Sciences $7(6), 431$.

Ali, A. J. (2014). Innovation, happiness, and growth. Competitiveness Review, 24(1), 2-4. https://doi.org/10.1108/CR-09-2013-0075

Alm, J., et al. (2010). Taxpayer information assistance services and tax compliance behavior. $\begin{array}{llll}\text { Journal of Economic } & \text { Psychology, } & 31(4), & \text { 577-586. }\end{array}$ https://doi.org/10.1016/j.joep.2010.03.018

Andreas \& E. Savitri (2015). The Effect of Tax Socialization, Tax Knowledge, Expediency of Tax ID Number and Service Quality on Taxpayers Compliance with Taxpayers Awareness as Mediating Variables. Procedia - Social and Behavioral Sciences, 211, 163-169. https://doi.org/10.1016/j.sbspro.2015.11.024

Arvin, M., \& B. Lew (2014). Does income matter in the happiness-corruption relationship? Journal of Economic Studies, 41(3), 469-490. https://doi.org/10.1108/JES-02-2013-0024

Aydin, N. (2012). A grand theory of human nature and happiness. Humanomics, 28(1), 42-63. https://doi.org/10.1108/08288661211200988

Barnard-Wills, D. (2017). The technology foresight activities of European Union data protection authorities. Technological Forecasting and Social Change, 116, 142-150. https://doi.org/10.1016/j.techfore.2016.08.032

Carfora, A., et al. (2017). Regional tax evasion and audit enforcement. Regional Studies, 1-12. http://dx.doi.org/10.1080/00343404.2017.1299934

D.H. Ackley, G.E. Hinton \& T.J. Sejnowski. (1985). A learning algorithm for Boltzmann machine, Cognitive Science, 9, 147-169.

Dean, A., \& P. Gibbs (2015). Student satisfaction or happiness?: A preliminary rethink of what is important in the student experience. Quality Assurance in Education, 23(1), 5-19. https://doi.org/10.1108/QAE-10-2013-0044

DeBats, D. A. (2008). A Tale of Two Cities: Using Tax Records to Develop GIS Files for 
Mapping and Understanding Nineteenth-Century U.S. Cities. Historical Methods: A Journal of Quantitative and Interdisciplinary History, 41(1), 17-38. http://dx.doi.org/10.3200/HMTS.41.1.17-38

Finley, M. I. (1999). The ancient economy. Univ of California Press.

Grosu, E. F., et al. (2014). Neuro-linguistic Programming based on the Concept of Modelling. Procedia - Social and Behavioral Sciences, 116, 3693-3699.

GSIS, “evolution of employment for the Greek Public Sector as per 1/1/2017” [WWW page]/ URL http://apografi.yap.gov.gr/apografi/2015/Flows_2015E.htm

Hassan, Hasjazura Binti, \& Syed Mohd Shafeq Bin Syed Mansor. (2014). Nlp Swish Pattern Therapy In Addressing The Problem Of Sleep Among Students. International Education Postgraduate Seminar 2014.

Hornung, B. R. (2006). Happiness and the pursuit of happiness: A sociocybernetic approach. Kybernetes, 35(3/4), 323-346. https://doi.org/10.1108/03684920610653656

Howes, D. (2015). Senses, Anthropology of the A2 - Wright, James D. International Encyclopedia of the Social \& Behavioral Sciences (Second Edition). Oxford, Elsevier: 615-620.

Kanavas, B., \& A. Zisopoulos (2017). Administrative Legislation for Tax Payoff by Combining Tax Payments, Land Allotment, Service Concession under Humanitarian Approach. Journal of Finance and Accounting 5(1), 6-13. https://doi.org/10.12691/jfa-5-1-2

Kirchler, E., et al. (2006). Shared subjective views, intent to cooperate and tax compliance: Similarities between Australian taxpayers and tax officers. Journal of Economic Psychology, 27(4), 502-517.

Lenhart, John M. (1943). The Capuchin Prefecture of New England (1630-1656). Franciscan Studies, New Series, 3(3), 306-13. http://www.jstor.org/stable/23801508.

Lester, D. (1990). Maslow's hierarchy of needs and personality. Personality and Individual Differences, 11(11), 1187-1188.

López, J. J. (2017). A quantitative theory of tax evasion. Journal of Macroeconomics, 53, 107-126. https://doi.org/10.1016/j.jmacro.2017.06.005

Merks, Paulus. (2006). Tax evasion, tax avoidance and tax planning. Intertax, 34, 272.

Nevis, Edwin C., ed. (2014). Gestalt therapy: Perspectives and applications. CRC Press.

Noltemeyer, A., et al. (2012). The relationship among deficiency needs and growth needs: An empirical investigation of Maslow's theory. Children and Youth Services Review, 34(9), 1862-1867.

Pavlitsas K., et all. (2009). EUHARMONIC, a universal multi sensor personal space recorder with secure digital forensic evidence qualification, 3rd International Conference 


\section{Macrothink}

OnCommunications And Information Technology, Athens 15 Dec 2009, pp. 213-217

Pavlitsas K., \& Sarianidis N. (2009). The impact of monopoly level on the development of

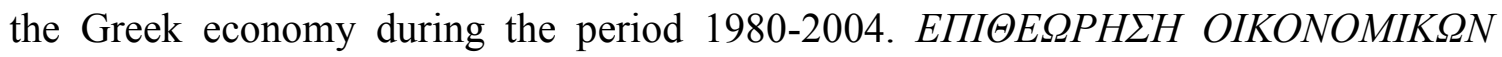
EПIГTHM $\Omega N, 16,171-182$.

Pilehvar, M. T., \& R. Navigli (2015). From senses to texts: An all-in-one graph-based approach for measuring semantic similarity. Artificial Intelligence, 228, 95-128. https://doi.org/10.1016/j.artint.2015.07.005

Pryce-Jones, J., \& J. Lindsay (2014). What happiness at work is and how to use it. Industrial and Commercial Training, 46(3), 130-134 https://doi.org/10.1108/ICT-10-2013-0072

Qiao, M., et al. (2017). Diversified dictionaries for multi-instance learning. Pattern Recognition, 64, 407-416. https://doi.org/10.1016/j.patcog.2016.08.026

ROBERTSON, M. F. (1969). The Pursuit of Happiness-at Work. Management Decision $3(3), 47-49$.

Sanusi, Aminuddin bin M., Syed Mohamed Shafeq \& Yahya Buntat. (2014). Neuro Linguistic Programming: Swish Therapy To Prevent Truancy Among Students In A Public School In Malaysia." International Education Postgraduate Seminar 2014.

Staemmler, Frank-M. (2016). Aggression, time, and understanding: Contributions to the evolution of Gestalt therapy. CRC Press.

Stankevicius, E., \& L. Leonas. (2015). Hybrid Approach Model for Prevention of Tax Evasion and Fraud. Procedia - Social and Behavioral Sciences, 213, 383-389. https://doi.org/10.1016/j.sbspro.2015.11.555

States, U., \& T. Jefferson (1952). The declaration of independence. Encyclopedia Britannica.

Stranovská, E., et al. (2013). Linguistic Intervention Programme. Procedia - Social and Behavioral Sciences, 93, 814-819. https://doi.org/10.1016/j.sbspro.2013.09.285

Thomsen, R. (1964). Eisphora: A Study of Direct Taxation in Ancient Athens (Vol. 3). Gyldendal.

Walch, C. W. F. (1755). De obedientia Christi activa commentatio.

Williams, D. E., \& M. M. Page (1989). A multi-dimensional measure of Maslow's hierarchy of needs. Journal of Research in Personality, 23(2), 192-213.

Yao, T., et al. (2017). Learning universal multiview dictionary for human action recognition. Pattern Recognition, 64, 236-244. https://doi.org/10.1016/j.patcog.2016.11.012

Young, Peter. (2017). Towards a research tradition in Gestalt therapy [Book Review]. Gestalt Journal of Australia and New Zealand, 13(2), 85.

Zavei, S. J. A. P., \& M. M. Jusan. (2012). Exploring Housing Attributes Selection based on Maslow's Hierarchy of Needs. Procedia - Social and Behavioral Sciences, 42, 311-319.e, 


\section{Macrothink}

https://doi.org/10.1016/j.sbspro.2012.04.195

\section{Copyright Disclaimer}

Copyright for this article is retained by the author(s), with first publication rights granted to the journal.

This is an open-access article distributed under the terms and conditions of the Creative Commons Attribution license (http://creativecommons.org/licenses/by/3.0/). 